\title{
Craniometric study of the Orbital Index in brazilian skulls
}

\section{Estudo craniométrico do Índice Orbitário em crânios humanos brasileiros}

\author{
Larissa Chaves Cardoso FERNANDES ${ }^{1}$ iD https://orcid.org/0000-0003-3136-6585 \\ Patrícia Moreira RABELLO2 ${ }^{2}$ https://orcid.org/0000-0001-5433-6982 \\ Bianca Marques SANTIAGO2,3 iD https://orcid.org/0000-0001-9559-913X \\ Marcus Vitor Diniz de CARVALHO4 ${ }^{4}$ https://orcid.org/0000-0003-1270-2352 \\ Manoel Raimundo de SENA JÚNIOR ${ }^{5}$ iD https://orcid.org/0000-0002-3693-4003 \\ Evelyne Pessoa SORIANO3,4 ID https://orcid.org/0000-0001-8337-0194 \\ Eduardo DARUGE JÚNIOR ${ }^{1}$ iD https://orcid.org/0000-0001-6565-3203
}

\section{ABSTRACT}

Objetive: To determine the percentage of correctness of the Orbital Index (OI) for estimation of sex, ancestry and age in Brazilian skulls. Methods: Cross-sectional study of 183 human dry skulls from the southeastern Brazil. A total of 100 skeletons were males and 83 females; of which 36 were aged up to 39 years, 60 aged between 40 and 59 years, and 87 aged 60 years or older. As for ancestry, 103 were from white, 51 mixed race, and 29 black individuals. The Ol was calculate by the formula = height/width $\times 100$. The data were submitted to Student's t test, F (ANOVA), Tukey and Kruskal Wallis tests as well as to discriminant analysis, with a $5 \%$ significance level. Results: The sample was characterized as mesoseme, with a mean age of $56.62( \pm 19.97)$ years. No significant difference was observed $(p=0.511)$ between the $\mathrm{OI}$ in females (right: $86.43 \pm 6.58$ and left: $86.70 \pm 5.93$ ) and males (right: $85.78 \pm 6.69$ and left: $86.37 \pm 6.20)$. There were no significant differences between age, ancestry and the variables analyzed ( $p>0.05)$. The right and left orbital widths were significantly dimorphic between sexes $(p<0.001)$. The percentage of correctness of the method for estimation of sex, age and ancestry was found to be $65.6 \%, 43.7 \%$, and $43.6 \%$, respectively. Conclusion: The Ol is not an appropriate method for estimation of sex, ancestry and estimation of age in this Brazilian sample. The methodology should be expanded to other population groups so that it can be improved.

Indexing terms: Age groups. Ethnic groups. Forensic anthropology. Orbit. Sexual dimorphism. Skull.

\footnotetext{
$\nabla \nabla \nabla$

1 Universidade Estadual de Campinas, Faculdade de Odontologia, Departamento de Odontologia Social, Divisão de Odontologia Legal. Av. Limeira, 901, Areião, 13414-903, Piracicaba, SP, Brasil. Correspondence to: LCC FERNANDES. E-mail: <larissaccfernandes@gmail.com>.

2 Universidade Federal da Paraíba, Federal University of Paraíba, Departamento de Odontologia Clínica e Social, Divisão de Odontologia Legal. João Pessoa, PB, Brasil.

${ }^{3}$ Instituto de Política Científica, Departamento de Medicina Legal e Odontologia. João Pessoa, PB, Brasil.

${ }^{4}$ Universidade de Pernambuco, Faculdade de Odontologia, Programa de Pós-Graduação em Medicina Legal, Divisão de Odontologia Legal. Camaragibe, PE, Brasil.

5 Universidade Federal de Pernambuco Federal, Departamento de Estatística. Recife, PE, Brasil.
}

$\boldsymbol{\nabla} \boldsymbol{\nabla} \boldsymbol{\nabla}$

How to cite this article

Fernandes LCC, Rabello PM, Santiago BM, Carvalho MVD, Sena Júnior MR, Soriano EP, et al Craniometric study of the Orbital Index in brazilian skulls. RGO, Rev Gaúch Odontol. 2021;69:e2021013. http://dx.doi.org/10.1590/1981-86372021001320190115 


\section{RESUMO}

Objetivo: Determinar a porcentagem de correlação do Índice Orbitário (IO) na estimativa do sexo, da ancestralidade e da idade em crânios brasileiros. Métodos: Estudo de corte transversal de 183 crânios secos humanos do sudeste brasileiro. No total, 100 esqueletos eram homens e 83 mulheres; dos quais 36 tinham até 39 anos, 60 tinham entre 40 e 59 anos e 87 tinham 60 anos ou mais. Quanto à ascendência, 103 eram brancos, 51 pardos e 29 negros. O 10 foi calculado pela fórmula = altura / largura x 100 . Os dados foram submetidos aos testes t de Student, F (ANOVA), Tukey e Kruskal Wallis, bem como à análise discriminante, com nível de significância de 5\%. Resultados: A amostra foi caracterizada como mesoseme, com média de idade de 56,62 ( $\pm 19,97)$ anos. Não houve diferença significativa $(p=0,511)$ entre o 10 no sexo feminino (direita: 86,43 $\pm 6,58$ e esquerda: 86,70 \pm 5,93) e do sexo masculino (direita: $85,78 \pm 6,69$ e esquerda: $86,37 \pm 6,20$ ). Não houve diferenças significativas entre idade, ancestralidade e as variáveis analisadas ( $p>$ $0,05)$. As larguras orbitais direita e esquerda foram significativamente dimórficas entre os sexos $(p<0,001)$. A porcentagem de acerto do método para estimativa de sexo, idade e ancestralidade foi de 65,6\%, 43,7\% e 43,6\%, respectivamente. Conclusão: 0 IO não é um método apropriado para estimativa de sexo, ancestralidade e estimativa de idade nesta amostra brasileira. A metodologia deve ser expandida para outros grupos populacionais para que possa ser aperfeiçoada.

Termos de indexação: Grupos etários. Grupos étnicos. Antropologia forense. Dimorfismo sexual. Órbita. Crânio.

\section{INTRODUCTION}

Cranial reference measures have been essential to distinguish between normal variability and abnormalities in the diagnostic assessment of neurological diseases [1,2]. Likewise, the morphometric analysis of the bone skeleton has also been useful for the forensic anthropologist to determine the ancestry of a set of bone remains [3]. By using visual and metric comparison of unknown bones with those of known origin [4], the study of human dry skulls can provide important information to support the anthropological characterization (sex, age, ancestry and height) [5]. These approaches may aid in the human identification process with up to $90 \%$ precision when analyzed separately $[5,6]$.

Orbits are conical cavities of the facial skeleton located at both sides of the sagittal plane and composed of the maxillary, zygomatic, lacrimal, palatine, frontal, ethmoidal and sphenoidal bones $[2,5,7]$. The orbital architecture has been used for estimation of human ancestry and sex for over 100 years $[5,8,9]$. Men usually have squared, small orbital cavities, while women are frequently found with round, thin orbital cavities $[5,10]$. As for ancestry, Africans have rectangular orbits, northern and southern Europeans present angular orbits, while central Europeans and Asians have orbits with a round shape [10].

The orbital cavity has width greater than height in most cases, and such a relationship is given by the Orbital Index (OI). This index was developed in 1875 by Paul Broca with the purpose of performing a quantitative assessment of the orbital size and symmetry. The index is based on the ration of height over width multiplied by $100[2,5,10]$.

It has been known that identification is a paramount need of forensic experts [5] and that variations in the morphometric features of the head and neck - and consequently of the orbits - may occur when different populations are compared. Thus, the present study aimed to determine the percentage of correctness of the Orbital Index for estimation of sex and estimation of age and ancestry in a Brazilian population by performing direct measurements in human skulls.

\section{METHODS}

This study is in accordance with the 466/12 Resolution of the National Health Council, Ministry of Health, Brazil. The project was previously submitted to and approved by the Research Ethics Committee of the Center for Health Sciences, Federal University of Paraíba, under protocol 1.157.688 and CAAE 45781415.0.1001.5188.

This was a cross-sectional study with a universe of 192 skeletons previously cataloged with regard to sex, ancestry and age at death (according to death certificate, an official document required for burial in Brazil). The samples were obtained from the Professor Eduardo Daruge Laboratory of Forensic Physical Anthropology at Piracicaba Dental School, University of Campinas (FOP/UNICAMP). After thorough analysis, we excluded from the sample the skulls with malformations, severe abnormalities, apparent trauma and/or serious bone pathologies, which could compromise the right and/or left orbital cavities. The final sample was composed of 183 human dry skulls.

For this sample, the confidence level is $95 \%$, with a margin of error of $7 \%$, which means that we have $95 \%$ confidence that the difference between a given estimated proportion and an actual ratio is less than or equal to 
$7 \%$. In numerical terms, the value of $n=192$, satisfies the condition: $P(|\hat{p}-p| \leq 0.07)=0.95$, where $\mathrm{n}$ appears as the denominator of the variance of the proportion estimator, ie: $\operatorname{Var}(\hat{p})=\frac{(p(1-p)}{n}$, where 1.96 is the upper quantile of the standard normal distribution, the probability of which the modulus of a variable with that distribution does not exceed this quantile is $95 \%$, numerically if $Z$ has a standard normal distribution, we have: $\mathrm{P}(|Z| \leq 1.96)=0.95$. Recalling that doing $Z=|\hat{p}-p|, Z$ has approximately standard normal distribution.

$$
\sqrt{(\operatorname{Var}(\hat{p})}
$$

The study variables included sex (male and female); ancestry (white, mixed race and black); age range (up to 39 years; between 40 and 59 years; and 60 years or older); orbital height $(\mathrm{OH}=$ supraorbital foramen to infraorbital foramen); orbital width (OW = maxillofrontal to orbital frontomalar) in both sides (right and left); and orbital index (microseme, mesoseme, and megaseme).

In each orbital cavity (right and left) we analyzed the anatomical points corresponding to the supraorbital foramen (SOF), infraorbital foramen (IOF) and the maxillofrontal (MF) and orbital frontomalar (OFM) points.

A digital caliper (Stainless-Hardened ${ }^{\circledR}$ - 150 mm, Mauá, São Paulo, Brazil) was used to perform linear measurements of the right and left orbital cavities, as follows: orbital height $(\mathrm{OH})=$ supraorbital foramen (SOF) $\leftrightarrow$ infraorbital foramen (IOF) (Figure 2); and orbital width (OW) = maxillofrontal (MF) point $\leftrightarrow$ orbital frontomalar (OFM).

The Orbital Index was calculated based on the formula: $\mathrm{Ol}=$ orbital height/ orbital width, multiplied by 100 [11]. After the Ol was obtained, the corresponding sample was categorized into one of the three patterns of orbital cavities reported in the literature [12-14]: a) microseme (small), OI $<83$ and ancestry characteristic of black races (orbital opening is rectangular); b) mesoseme (intermediate), Ol between 83-89 and ancestry characteristic of white races Europeans and English have values of 87 and 88.4, respectively; and c) megaseme (big), $\mathrm{Ol}>89$ and ancestry characteristic of yellow races, except for the Esquimaux (Eskimos) whose orbital opening is round.

Due to the high sensibility of the digital caliper, its tips were approximated after each measurement and the caliper was zeroed, in order to avoid possible variations of the equipment that could interfere with the results.
A pilot study was previously performed to calibrate the examiner following the same criteria adopted for the full length study. A total of 25 dry skulls were selected from the Bone Collection and then analyzed. Two assessments were carried out within a seven-day interval to check for examiner's agreement. The Kappa statistics was found to be $\geq 0.92$, which indicated rigorous agreement. No adjustments were necessary based on the pilot study, therefore all skulls analyzed at this stage were also included in the final sample, totaling 183 samples.

The data were treated descriptively and inferentially by Student's $t$ test with equal variances, Mann-Whitney, $F$ (ANOVA) and Kruskal Wallis, with a 5\% significance level $(p \leq 0.05)$. All analyses were performed using the Statistical Package for Social Sciences, version 23.0 (SPSS Inc., Chicago, IL, USA). Discriminant analysis was applied to determine the percentage of correctness of the method for estimation of sex, age and ancestry. This type of analysis provides a pondering function according to the value of each metric and variable.

\section{RESULTS}

A total of 183 skulls were analyzed, of which 100 (54.6\%) were from males and 83 (45.4\%) from females, with a mean and median age of 56.26 19,97 and 58.00, respectively. The standard deviation was found to be 19.97 years, which indicated a mild variability as the deviation was lower than half the value of the corresponding mean. As for age, most skulls corresponded to individuals aged 60 years $(47.5 \%)$ or older at death, followed by those aged 40 to 59 years $(32.8 \%)$ and up to 39 years $(19.7 \%)$. The majority derived from the white ancestry (56.3\%), followed by mixed race (27.9\%) and black (15.8\%).

The following measurements (mean \pm standard deviation) were obtained: right orbital height (33.87 \pm 2.61$)$; left orbital height $(33.98 \pm 2.32)$; right orbital width $(39.47 \pm 1.94)$; left orbital width (39.32 \pm 1.90$)$; right OI $(86.08 \pm 6.63)$; left OI $(86.52 \pm 6.06)$. The sample was characterized as mesomeme (OI between 83 and 89).

With regard to sex, significant differences were observed only between sex and the right and left orbital width $(p<0.05)$. These variables were found to have means correspondingly higher in males than females (Table 1). 
Table 1. Distribution of the sample by sex according to the right and left orbital height and width and the Orbital Index.

\begin{tabular}{|c|c|c|c|}
\hline \multicolumn{4}{|c|}{ Sex } \\
\hline $\mathrm{n}=183$ & Male & Female & $p$-value \\
\hline & Mean \pm SD (Median) & Mean \pm SD (Median) & \\
\hline Right Orbital Height & $34.17 \pm 2.56(34.27)$ & $33.51 \pm 2.64(33.62)$ & $p^{(1)}=0.123$ \\
\hline Left Orbital Height & $34.28 \pm 2.15(34.31)$ & $33.61 \pm 2.48(33.77)$ & $p^{(1)}=0.092$ \\
\hline Right Orbital Width & $40.02 \pm 1.86(40.07)$ & $38.79 \pm 1.83(38.75)$ & $\mathrm{p}^{(1)}<0.001^{*}$ \\
\hline Left Orbital Width & $39.75 \pm 1.79$ (39.89) & $38.79 \pm 1.91(38.60)$ & $p^{(1)}=0.001^{*}$ \\
\hline Right Orbital Index & $85.78 \pm 6.69(84.99)$ & $86.43 \pm 6.58(87.67)$ & $p^{(1)}=0.511$ \\
\hline Left Orbital Index & $86.37 \pm 6.20(85.99)$ & $86.70 \pm 5.93(87.79)$ & $p^{(1)}=0.713$ \\
\hline
\end{tabular}

Note: ${ }^{*}$ : : Signficant difference at $5.0 \%$. (1): Student's t test with equal variances.

None of the variables analyzed showed significant difference $(P>0.05)$ in relation to age range and ancestry, as shown in Tables 2 and 3.

The percentage of correctness of the orbital measurements for estimation of sex, age and ancestry is given in tables 4, 5 and 6 . The method properly determined sex in $65(65 \%)$ out of the 100 male skulls and failed to do so in 35 (35\%) of them by mistaking female with male sex. Furthermore, the method properly determined sex in $55(66.3 \%)$ out of the 83 female skulls, failing in 28 cases (33.7\%). Therefore, this method presented a percentage of correctness of $65.6 \%$ for sex estimation.

Table 2. Distribution of the sample by age range according to the right and left orbital height and width and the Orbital Index.

\begin{tabular}{|c|c|c|c|c|}
\hline \multicolumn{5}{|c|}{ Age range } \\
\hline$n=183$ & Up to 39 years & 40 to 59 years & 60 years or older & \multirow{2}{*}{$p$-value } \\
\hline & Mean \pm SD (Median) & Mean \pm SD (Median) & Mean \pm SD (Median) & \\
\hline Right Orbital Height & $33.53 \pm 2.25(33.26)$ & $33.64 \pm 2.77(33.73)$ & $34.17 \pm 2.63(34.44)$ & $\mathrm{p}^{(1)}=0.338$ \\
\hline Left Orbital Height & $33.75 \pm 2.28(33.67)$ & $33.76 \pm 2.34$ (33.99) & $34.22 \pm 2.33(34.41)$ & $p^{(1)}=0.404$ \\
\hline Right Orbital Width & $39.24 \pm 1.98$ (39.29) & $39.81 \pm 2.05(39.63)$ & $39.33 \pm 1.84(39.50)$ & $p^{(1)}=0.252$ \\
\hline Left Orbital Width & $39.02 \pm 2.11(39.11)$ & $39.61 \pm 1.93(39.65)$ & $39.23 \pm 1.78(39.54)$ & $p^{(1)}=0.288$ \\
\hline Right Orbital Index & $86.40 \pm 6.15(86.55)$ & $84.64 \pm 6.80(84.27)$ & $86.94 \pm 6.61(87.12)$ & $p^{(1)}=0.113$ \\
\hline Left Orbital Index & $86.62 \pm 6.23(86.89)$ & $85.30 \pm 5.58(84.94)$ & $87.33 \pm 6.24(87.82)$ & $p^{(1)}=0.137$ \\
\hline
\end{tabular}

Note: (1): F test (ANOVA).

Table 3. Distribution of the sample by ancestry according to the right and left orbital height and width and the Orbital Index.

\begin{tabular}{|c|c|c|c|c|}
\hline & & Ancestry & & \\
\hline \multirow[t]{2}{*}{$n=183$} & White & Black & Mixed Race & \multirow{2}{*}{$p$-value } \\
\hline & Mean \pm SD (Median) & Mean \pm SD (Median) & Mean \pm SD (Median) & \\
\hline Right Orbital Height & $33.63 \pm 2.55(33.78)$ & $34.64 \pm 2.67(34.64)$ & $33.92 \pm 2.66(34.64)$ & $\mathrm{p}^{(1)}=0.155$ \\
\hline Left Orbital Height & $33.70 \pm 2.39(33.79)$ & $34.53 \pm 2.24(34.60)$ & $34.22 \pm 2.19(33.80)$ & $p^{(1)}=0.109$ \\
\hline Right Orbital Width & $39.39 \pm 2.02(39.56)$ & $39.95 \pm 1.92(39.95)$ & $39.35 \pm 1.80(39.15)$ & $p^{(1)}=0.289$ \\
\hline Left Orbital Width & $39.12 \pm 1.88(39.30)$ & $39.94 \pm 1.96(40.02)$ & $39.36 \pm 1.88(39.51)$ & $\mathrm{p}^{(2)}=0.118$ \\
\hline Right Orbital Index & $85.49 \pm 6.65(85.02)$ & $87.81 \pm 5.64(87.64)$ & $86.29 \pm 7.03(85.90)$ & $p^{(2)}=0.243$ \\
\hline Left Orbital Index & $86.26 \pm 6.46(85.71)$ & $86.54 \pm 5.38(86.64)$ & $87.05 \pm 5.67(87.00)$ & $\mathrm{p}^{(2)}=0.747$ \\
\hline
\end{tabular}

Note: ${ }^{(1)}$ : F test (ANOVA) with Tukey's pairwise comparisons. ${ }^{(2)}$ : Kruskal Wallis with pairwise comparisons. 
Table 4. Percentage of correctness of the right and left orbital height and width and the Orbital Index for determination of sex.

\begin{tabular}{|c|c|c|c|c|c|c|}
\hline \multirow{3}{*}{ Sex } & \multicolumn{4}{|c|}{ Predicted Group Membership } & \multirow{2}{*}{\multicolumn{2}{|c|}{ Total }} \\
\hline & \multicolumn{2}{|c|}{ Male } & \multicolumn{2}{|c|}{ Female } & & \\
\hline & $\mathrm{n}$ & $(\%)$ & $\mathrm{n}$ & $(\%)$ & $n$ & $(\%)$ \\
\hline Female & 28 & (33.7) & 55 & $(66.3)$ & 83 & $(100.0)$ \\
\hline
\end{tabular}

Note: $65.6 \%$ of original grouped cases correctly classified.

Table 5 shows the percentage of correctness of the study variables for age estimation. Our findings revealed that $17(47.2 \%)$ out of the 36 previously cataloged skeletons aged up to 39 years were properly estimated. On the other hand, a total of $9(25.0 \%)$ skulls were mistakenly estimated as being aged 40 to 59 years and 10 of them $(27.8 \%)$ as 60 years or older. A total of $28(46.7 \%)$ and $35(40.2 \%)$ skulls previously cataloged as 40 and 59 years, and 60 years or older, were properly estimated based on the orbital measurements presented herein. Hence, this method presented a percentage of correctness of $43.7 \%$ for age estimation.

Table 6 shows the percent percentage of correctness of the orbital variables for estimation of ancestry in the Brazilian population. Of the 103 dry skulls previously cataloged into the white ancestry, 58 (56.3\%) were correctly classified as such, whereas 17 (16.5\%) and
$28(27.2 \%)$ were mistakenly categorized as black and mixed race, respectively. A total of 16 (55.2\%) and 24 (47.1\%) skulls were properly classified into the black and mixed race ancestry, respectively. Therefore, this method was able to correctly determine ancestry in this Brazilian population with a percentage of correctness of $43.6 \%$.

No significant differences between the right and left sides were observed for any of the variables analyzed.

\section{DISCUSSION}

Since 1993 scientific tests have been considered a forensic technical requirement in the courts of justice. Only the tests undergoing thorough peer review and validation, as well as acceptance by the scientific community as a reliable method for human individualization, should be

Table 5. Percentage of correctness of the right and left orbital height and width and the Orbital Index for estimation of age.

\begin{tabular}{|c|c|c|c|c|c|c|c|c|}
\hline \multirow{3}{*}{ Age range } & \multicolumn{6}{|c|}{ Predicted Group Membership } & \multirow{2}{*}{\multicolumn{2}{|c|}{ Total }} \\
\hline & \multicolumn{2}{|c|}{ Up to 39 years } & \multicolumn{2}{|c|}{40 to 59 years } & \multicolumn{2}{|c|}{60 years or older } & & \\
\hline & $\mathrm{n}$ & $(\%)$ & $\mathrm{n}$ & $(\%)$ & $n$ & $(\%)$ & $n$ & $(\%)$ \\
\hline 40 to 59 yrs & 16 & $(26.7)$ & 28 & $(46.7)$ & 16 & $(26.7)$ & 60 & $(100.0)$ \\
\hline 60 yrs or older & 30 & (34.5) & 22 & (25.3) & 35 & $(40.2)$ & 87 & $(100.0)$ \\
\hline
\end{tabular}

Note: $43.7 \%$ of original grouped cases correctly classified.

Table 6. Percentage of correctness of the right and left orbital height and width and the Orbital Index for determination of ancestry.

\begin{tabular}{|c|c|c|c|c|c|c|c|c|}
\hline \multirow{3}{*}{ Ancestry } & \multicolumn{6}{|c|}{ Predicted Group Membership } & \multirow{2}{*}{\multicolumn{2}{|c|}{ Total }} \\
\hline & \multicolumn{2}{|c|}{ White } & \multicolumn{2}{|c|}{ Black } & \multicolumn{2}{|c|}{ Mixed Race } & & \\
\hline & $\mathrm{n}$ & $(\%)$ & $n$ & $(\%)$ & $\mathrm{n}$ & $(\%)$ & $n$ & $(\%)$ \\
\hline Black & 5 & $(17.2)$ & 16 & $(55.2)$ & 8 & $(27.6)$ & 29 & $(100.0)$ \\
\hline Mixed Race & 11 & (21.6) & 16 & (31.4) & 24 & $(47.1)$ & 51 & $(100.0)$ \\
\hline
\end{tabular}

Note: $43.6 \%$ of original grouped cases correctly classified. 
employed [10]. When human identification approaches are based on population parameters the study of each specific group becomes necessary, given that interethnic crosses generate individuals with metric and morphological peculiarities.

Brazil is the largest and most populous country in Latin America. With more than 200 million inhabitants, it is considered as one of the classic models of the outcome of mixtures among human populations $[15,16]$. This is the result of half a century of interethnic crosses among the native Brazilian population (Brazilian Indians), Amerindians (native Americans), Europeans, and Africans [17]. The matter of miscegenation in Brazil is remarkable in such a way that regionalized subpopulations can be found. These subgroups are marked by greater or lesser ancestral contribution of the above listed peoples, making phenotypic distinction not always a possible task.

The skeletons used in our study were obtained from a cemetery in the state of São Paulo, Brazil, which is the richest and most developed state in the nation. A high influx of people is attracted to São Paulo from other territorial areas as well as from abroad, in particular, Japan [16].

The orbital measurements of an individual may vary based on sex and ancestry [10,18-21]. In 2014, Indian researchers [18] investigated the orbital measurements of 200 human dry skulls (130 males and 70 females) from southern India, one of the most mixed population in the world. The authors found that the mean Ol of males (81.13) was lower than that of females (82.32). These findings are in agreement with those reported herein for males (right and left OI of 85.78 and 86.37 , respectively) and females (right and left OI of 86.43 and 86.70 , respectively).

In addition to assisting in anthropological characterization and human identification, the study of the Orbital Index has also been useful for the clinical and surgical treatment of orbital diseases [22]. This highlights a clear need for further regional studies to support better therapies based on the knowledge of peculiar features of each single population from across the globe.

The orbital cavity usually has height greater than width and can be classified into three types [12-14,21]: microseme, mesoseme, and megaseme. The Brazilian population in this study was characterized as mesoseme. Other researchers have found different results with other populations. Suzuki [23] showed that the predominant orbital type in eastern Asia was the microseme, while
Ukoha and collaborators [22] characterized the orbits of Nigerians as megaseme.

Morphologically, the female orbit is larger, rounder, upwardly positioned and with sharper margins compared to the male orbit, which is smaller, more squared, downwardly positioned and with round margins $[6,8]$. Husmann and Samson [10] evaluated the Orbital Index proposed by Broca among the American population. The authors observed significant differences based on sex. However, a more in-depth analysis revealed that such differences did not have much practical usefulness and therefore should not be considered for estimation of sex and ancestry. These results corroborate those found in our study with Brazilians, in which the orbital height and width and the OI showed reasonable percentage of correctness for sex estimation $(65.6 \%)$ but were not effective for estimation of age (43.7\%) and ancestry (43.6\%).

Forensic literature does not have reference tables that relate orbital measurements, including the orbital index, to sex estimation and age estimation. In the attempt to establish such parameters for the Brazilian population, the present study verified the applicability of such variables as auxiliary methods in the identification of Brazilian bone remains. Although the percentage of correctness was not satisfactory in this Brazilian sample, it may be in other populations, since the metric parameters are distinct.

Anthropometric studies using direct sizing in dry skulls minimize the possibility of altered measurements, since bones are evaluated under a more natural perspective [24]. The morphological variability expressed by different populations worldwide creates an obstacle to the identification practice by Forensic Sciences. Regression tables and formulas of a population group should not be used in allusion to others. Ideally, anthropometric surveys should be developed in each region.

Currently, only a few studies have been published in the field of Forensic Anthropology focusing on the Brazilian population [25]. The present study brings a perspective of the metric reality of the orbit of the Brazilian population and confirms that this group harbors unique features. Nevertheless, such morphological pattern should not be applied to human bone remains for estimation of sex, ancestry and age.

\section{CONCLUSIONS}

The study sample was characterized as mesoseme, with males having greater orbital width than females. 
The Orbital Index is an auxiliary method in the forensic identification process. Nevertheless, it should not be used for estimation of sex, ancestry and age in the Brazilian population due to unsatisfactory percentage of correctness.

This methodology must be tested in other Brazilian population groups to evaluate its applicability in other samples.

\section{Collaborators}

LCC FERNANDES, conception and design of the study; methodology; acquisition of data; formal analysis; investigation; analysis and interpretation of data; writing - review \& editing; visualization; project administration. PM RABELLO, writing - review \& editing; visualization; final approval of the version. BM SANTIAGO, methodology; validation; acquisition of data; formal analysis; investigation; writing - review \& editing; final approval of the version. MVD CARVALHO, conception and design of the study; methodology; software; writing - review \& editing; supervision. MR SENA JÚNIOR, methodology; validation; acquisition of data; formal analysis; analysis and interpretation of data; investigation; writing - review \& editing; final approval of the version. EP SORIANO, methodology; validation; acquisition of data; formal analysis; investigation; writing - review \& editing; final approval of the version. E DARUGE JÚNIOR, conception and design of the study; Writing - Review \& Editing; Visualization; Final approval of the version.

\section{Acknowledgments}

This study was financed in part by the Coordination of Improvement of Higher Education Personnel - Brazil (CAPES) Finance Code 1510870 - and by the Pernambuco Research and Technology Foundation (FACEPE).

\section{REFERENCES}

1. Kerber PZ, Macêdo EOD, Berthold TB. Diferenças nas medidas cefalométricas esqueléticas, dentárias e tegumentares de melanodermas e leucodermas - uma revisão da literatura. Rev Ciênc Méd Biol. 2018;17(1):67-73.

2. Gopalakrishna K, Kashinatha SM. The craniometrical study of orbital base of Indian population and its applied Importance. Sch Acad J Biosci. 2015;3(7):618-623.

3. Hefner JT, Spradley MK, Anderson B. Ancestry Assessment Using Random Forest Modeling. J Forensic Sci. 2014;59(3):583-589. http://dx.doi.org/10.1111/1556-4029.12402
4. Botwe BO, Sule DS, Ismael AM. Radiologic evaluation of orbital index among Ghanaians using CT scan. J Physiol Anthropol. 2017;36(29):1-6. http://dx.doi.org/10.1186/s40101017-0145-7

5. Biswas S, Chowdhuri S, Das A, Mukhopadhyay PP. Observations on Symmetry and Sexual Dimorphism from Morphometrics of Foramen Magnum and Orbits In Adult Bengali Population. J Indian Acad Forensic Med. 2015;37(4):345-351. http://dx.doi. org/10.5958/0974-0848.2015.00090.1

6. Vanrell JP. Odontologia legal e antropologia forense. $3^{\mathrm{a}}$ ed. Rio de Janeiro: Guanabara Koogan; 2019.

7. Mekala D, Shubha R, Rohini - Devi M. Orbital dimensions and Orbital Index: a measurement study on South Indian dry skulls. IJAR. 2015;3(3):1387-91. http://dx.doi.org/10.16965/ ijar.2015.242

8. França GV. Medicina legal. $11^{\text {a }}$ ed. Rio de Janeiro: Guanabara Koogan; 2017.

9. Lima LNC, Oliveira OF, Sassi C, Picapedra A, Francesquini Júnior L, Daruge Júnior E. Sex determination by linear measurements of palatal bones and skull base. JFOS. 2012;30(1):37-44.

10. Husmann PR, Samson DR. In the Eye of the Beholder: Sex and Race Estimation using the Human Orbital Aperture. J Forensic Sci. 2011;56(6):1424-1429. http://dx.doi.org/10.1111/j.15564029.2011.01864.x

11. Gupta R, Kulshreshtha V, Gupta A, Garg S, Gupta A. A study of the orbital index of human dry skulls in population of uttar pradesh. J Anat Science. 2017;25(1):28-31.

12. Ezeuko VC, Om'Iniabohs FA, Udemezue OO. Igbos are predominantly microsemes: A radiologic study of the orbital rims of South Eastern Nigerians. Ann Biol. 2014;2(1):2-6. http://dx.doi.org/10.4103/2315-7992.143397

13. Ranasinghe AN, Yuvaraj Babu K, Mohanraj KG. Estimation of orbital index for gender determination. DIT. 2018;10(12)2408-2410.

14. Igbigbi PS, Ebite LE. Orbital Index of Adult Malawians. Anil Aggrawal's Internet J Forensic Med and Toxicol. 2010;11(1):[about 21 p].

15. Brito LC. The crime of miscegenation: racial mixing in slaveholding Brazil and the threat to racial purity in postabolition United States. Rev Bras Hist. 2016;36(72):1-24. http://dx.doi.org/10.1590/1806-93472016v36n72_007

16. Kehdy FS, Gouveia MH, Machado M, Magalhães WC, Horimoto AR, Horta BL, et al. Origin and dynamics of admixture in Brazilians and its effect on the pattern of deleterious mutations. Proc Natl Acad Sci EUA A. 2015;112(28):8696-8701. http://dx.doi.org/10.1073/pnas.1504447112

17. Durso DF, Bydlowski SP, Hutz MH, Suarez-Kurtz G, Magalhães TR, Pena SDJ. Association of Genetic Variants with Self-Assessed Color Categories in Brazilians. PLoS ONE. 2014; 9(1):e83926. http://dx.doi.org/10.1371/journal. pone.0083926

18. Patil GV, Shishirkumar T, Apoorva D, Sharif J, Sheshgiri C. Study of Orbital Index in Human Dry Skulls of South Indian Origin. IJHSR. 2014;4(9):125-128. 
19. Mekala D, Shubha R, Rohini DM. Orbital dimensions and orbital index: a measurements study on south indian dry skulls. Int J Anat Res. 2015;3(3):1387-1391. http://dx.doi. org/10.16965/ijar.2015.242

20. Orish CN, Ibeachu PC. Craniometric indices of Nigeria skulls. Int J Anat Appl Physiol. 2016 Jan;2(1):6-13.

21. Anibor E, Ighodae W. Orbital Index of adult binis in Edo State, Nigeria. Int. J of Forensic Med Invest. 2016; 2(1):17-19. http:// dx.doi.org/10.21816/ijfmi.v2i1.12

22. Ukoha U, Egwu OA, Okafor IJ, Ogugua PC, Onwudinjo O, Udemezue OO. Orbital dimensions of adult male nigerians: a direct measurement study using dry skulls. Int J Biol Med Res. 2011;2(3):688-690.
23. Suzuki $H$. Microevolutional changes in the Japanese population from prehistoric age to the present day. J Fac Sci. 1969;5(3):279-308.

24. Alam T, Rai R, Singh MK. Orbital dimensions and Orbital Index of adult human dry skulls: a direct measurement study. IJSR. 2016;5(1):523-524. http://dx.doi.org/10.16965/ijar.2015.242

25. Fernandes LCC, Carvalho MVD, Daruge Júnior E, Francesquini Júnior L, Rabello PM, Soriano EP. The nasal index in brazilian human skeletons. BJOS. 2018;17:e18337. http://dx.doi. org/10.20396/bjos.v17i0.8654156

Received on: 16/7/2019

Final version resubmitted on: 21/10/2019

Approved on: 22/11/2019 